\title{
The integration of disabled children into mainstream education in Belarus
}

\section{Tamara Varenova}

This article describes the development of the integration of children with different kinds of disabilities into mainstream education. The idea of integration, which was suggested and substantiated by the Belarusian-born psychologist Lev Vygotski (1896-1934), was recognized in western European schools and in the USA and has only recently started actively developing in Russia and in Belarus, the former Soviet Union. However, the concept of integrated education remains an object of controversial discussion. Mainstream education has its positive and negative features. It is not clear enough whether criteria such as social status, academic success and level of skills can provide the evidence that integrated education is or is not effective.

This article provides an insight into the integrative education system in Belarus. It describes the current situation of the use of special education and attitudes towards disabled children, and the professional training of educators who work with these children.

Key words: special education, disabled children, integration, mainstream education Varenova T (2003) The integration of disabled children into mainstream education in Belarus. Int J Ther Rehabil 10(9): ????

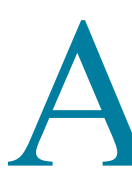
Organization, all over the world there are increasing numbers of children with special educational needs AQ: Please supply a reference for this. In addition, there is an increase in the number of children born not only with a single developmental defect but also with combined defects, i.e. multiple learning disabilities. This requires more qualitative intervention and diverse special help.

The pathology of children is universal in all types of societies. Special education is the field where interdisciplinary approaches and a wide exchange of international experience is needed to provide different ways of resolving general problems. This article provides an insight into the Belarusian educational culture; an interesting system for consideration.

Tamara Varenova is Head of Department at Belarusian State Pedagogical University, Storozhevskaya Street 8-190, Minsk 220002, Belarus

tamavar@hotbox.ru

\section{SOME FACTS AND FIGURES}

More than $11 \%$ of children in Belarus are disabled. Pre-school children make up $48 \%$ and school children make up $52 \%$ of handicapped children. Disorders of the nervous system are the most common type of handicap (39\%), followed by mental disorders (33\%) and defects related to the develop- ment of the skeletal and muscular systems and internal organs $(23 \%)$. The lowest proportion of child handicaps are illnesses of the sense organs, i.e. hearing and sight (5\%). While 14\% of handicapped children have serious and persistent defects of motor, mental or psychophysical function, $86 \%$ of disorders are of a less serious nature and can be more easily cured or compensated for.

The main purpose of special help is to prevent disability and increase the degree of function. With regard to providing for special help, three ministries carry out it in Belarus: the Ministry of Health Care, Ministry of Education and Ministry of Social Defence and Labour.

\section{WHAT IS EDUCATIONAL INTEGRATION?}

The original definition of the word 'integration' is 'unification of parts into the whole'. In the educational setting, it is the association of healthy children and children with psychophysical development problems into one group or institute. However, integration is not a mechanical combination of two parts. It unifies several social realities with the aim of creating a new level with equal communication, interaction and cooperation.

There are two actual approaches to integration: 
mainstreaming and inclusion. Research Bulletin No 11, 1993 from Phi Delta Kappa's Centre for Evaluation, Development and Research AQ: Please supply the full reference for this gives the following definitions:

Mainstreaming has been used to refer to the selective placement of special education students into one or more 'regular' education classes. Proponents of mainstreaming generally assume that a student must 'earn' his or her opportunity to be placed in regular classes by demonstrating an ability to keep up with the work assigned by the regular classroom teacher. This concept is closely linked to traditional forms of special education service delivery.

- Inclusion is a term that expresses commitment to educate each child, to the maximum extent appropriate, in the school and classroom he or she would otherwise attend. It involves bringing the support services to the child, rather than moving the child to the services. Proponents of inclusion generally favour newer forms of education delivery.

The Americans with Disabilities Act (ADA) of 1990 has clarified the rights and responsibilities of both sides. AQ: which sides do you mean? Decisions have built on the statutes and regulations prohibiting disability-based discrimination to produce a clearer definition of what pupils may ask for and schools must provide in the areas of admissions, academic adjustment and auxiliary aids (Milani, 1996). The ADA has opened doors for 49000000 Americans with disabilities. Discrimination against school children on the basis of handicap has been prohibited in education programmes or activities.

The Individuals With Disabilities Education Act of 1997 does not require inclusion. It contemplates that the 'least restrictive environment' is the regular education classroom. The author of this article agrees that the main idea of integrative education is to encourage the transition of integration at school to integration in society (Nazarova, 2000) AQ: (see ref list). Under Belarusian law, common education must guarantee the right of a disabled child not to be isolated and must give him or her the possibility to attend the school that he or she would have chosen if healthy, and receive goods and services on an equal basis to that of the rest of the general public.

Integrative education also helps the moral upbringing of normal children. The author shares the opinion that the fundamental principal of integrative education is that there are as few as possible external (social) differences and more internal (educational) differences (Konopleva and Leshinskaya, 2001).

Integrated education is taken as an alternative form of learning and this process in Belarus has an evolutionary characteristic. All classes and groups are formed on the basis of the conclusions of the centres of corrective and developing education and rehabilitation, which compare the educational benefits the child would receive in regular education (with supplemental aids and services) to the benefits in a special school. The centres are responsible in their district for a comprehensive investigation of the child's competence in different areas at the beginning and at the end of the academic year. Generally, the outcomes of integrated children are higher than those of segregated children.

\section{CRITERIA FOR SUCCESSFUL INTEGRATION INTO EDUCATION}

While deciding about the integration of disabled children into education, it is important to satisfy certain external and internal criteria (Shmatko, 1999).

\section{External criteria}

These include:

Early diagnosis and intervention

- Parental desire that their child will learn together with healthy children and be helped to gain knowledge

A realization that special help is needed to integrate the child

The establishment of conditions for the realization of different types of integrated education

The creation of barrier-free and adaptive environments.

\section{Internal criteria}

These include:

A level of psychophysical and language development according to the approximate norm for that child's age

- The possibility of mastering common educational standards in reasonable time

- Psychological readiness to integrative education (e.g. following class rules, working cooperatively and sharing materials with peers).

A well-founded selection of disabled children is one of the main ways to successful integration in education. Integration gives the possibility to choose what is best for a child, to create an alternative choice with a list of special services for the educational system.

The decision of common education can not be forced. It is taken on the basis of the conclusion of the centre after a comprehensive examination and under the agreement of the parents. There is a need to define not only 'the actual level of development' but also the 'zone of the nearest and perspective 
development', degree of education, teaching methods and conditions for correcting the cognitive sphere.

One of the most important arguments for deciding about integrated education is the social situation. A non-school environment can greatly influence a child's development both in a positive and negative way. The social status of the family of the child planned for integration should first be taken into account, along with the readiness and ability of the parents to cooperate with professionals during discussion about solving the child's problems (Rutkowski, 1998).

One of the tasks of correctional work in terms of integration is to change the interrelation between children with disabilities and those without. Ways of doing this are: harmonizing relationships among classmates; planning to identify educators to disabled people and make them feel better about their difficulties; including in-built activity for self-realization; and correcting deviation of behaviour.

Another important argument for determining effective education is the existence of special conditions in general institutions, such as designated adapted environments and special equipment and appliances that are appropriate given the disabled pupil, class and teacher variables.

\section{TYPES OF EDUCATION FOR DISABLED} CHILDREN IN BELARUS

At present, there are the following types of special education and integration in Belarus:

- Special schools and school hostels

- Integrated classes

- Special classes in general schools with 6-12 students (the number depends on the type and structure of defect)

Individual education at home

Education at medical institutes.

All of these are predominantly run by the state. In the past, there was mainly only a single form of education for disabled children - a special boarding school. A new tendency has now emerged: to reform weekly boarding schools into daily schools. Last academic year, there were 80 special school hostels and 12 special schools where disabled children undertook different activities from 9 am until $6 \mathrm{pm}$.

The centres of corrective and developing education and rehabilitation provide a new type of special help that has been growing in Belarus successfully. Over 10 years, about 100 such centres have been set up. Every centre pursues the following tasks:

Diagnosing disorders of psychophysical development of children

Providing correctional assistance
Providing social, psychological and medical rehabilitation for handicapped people

- Assessing readiness of pre-school children for school education

- Providing psychopedagogical and medical help for children with Chernobyl's syndrome

Consulting and presenting information for parents and educators.

The centres can organize work with children with one or several types of disability, with the aim of creating and developing a psychologically comfortable environment. It carries out research and study, identifying special needs to provide an appropriate education.

All centres aim to find ways in which education and training can minimize the risks of exclusion. They involve activities such as participation in national arts festivals, visits to theatres, travelling, excursions, summer camps with non-disabled children and part-time working at the enterprises in the programmes of social-based rehabilitation. Every Belarusian special school has a calendar plan of lessons off and weekend and holiday activities for the pupils.

A restructured system that merges special and regular education must use practices that focus on high expectations for all and reject the prescriptive teaching, remedial approach that leads to lower achievement (Heshusius, 1988).

\section{PROS AND CONS OF THE \\ INTEGRATION OF DISABLED CHILDREN}

AQ: Please provide references to any evidence on the pros and cons of integrative education Integrative education has positive and negative sides. Positive points include:

A stimulating influence of more successful classmates on other children

Expansion of the social environment

Development of communicative skills and nonstereotype thinking in both groups of pupils

- Real possibilities for showing patience, consolidation, sympathy and readiness to collaborate

In addition, placing a child in a special school is three to four times more expensive for the state than placing the child in a general school. By attending school together, both children with disabilities and those without can gain the attitudes, values and skills necessary to get along as interdependent members of society.

Unfortunately, there are also negative sides. Some pupils do not get on well with disabled classmates and show their negative feelings or prefer to stay indifferent rather than be friendly. Democratic values should be brought to each generation by creating the necessary conditions at educational 
establishments. The negative sides to integration are:

A heterogeneous group impacts on good pupils negatively and slows their development

- Competition is bad for disabled pupils and teachers cannot provide the necessary attention that disabled children need

- Teachers encounter unsolved moral problems in their work, which require more of their time and consideration.

There are a number of reviews and meta-analyses that consistently report little or no benefit for disabled students when they are placed in special education settings (Kavale and Glass, 1982; Madden and Slavin, 1983). However, in 50 studies comparing the academic performance of mainstreamed and segregated pupils with a mild disability, the mean academic performance of the integrated group was in the 80th percentile, while the segregated students scored in the 50th percentile (Weiner, 1985). Using this evidence, proponents of inclusion claim that segregated programmes are detrimental to school children and do not meet the original goals for special education.

More recent meta-analyses confirm a small to moderate beneficial effect of inclusional education on the academic and social outcome of specialneeds students (Baker et al, 1994). Piuma (1989) found that over a 15 -year period, the employment rate for high-school graduates with special needs who had been in segregated programmes was 53\% However, for special needs graduates from integrated programmes, the employment rate was $73 \%$.

Some scientists in special education are sceptical about common learning, but at the same time they do not reject this idea entirely. In their opinion, a special school is the best place for the upbringing of a child with disabilities because there, he or she is on the same level as others and his or her preparation to live in society may be more successful.

The process of upbringing, learning and developing in a special school is organized by professional people with special equipment, using special methods tailored to children's cognitive possibilities and capacities for work. Special schools have various workshops, where children can get jobs and professional training for future independent life. Children in special schools receive treatment that general schools cannot provide (Gudonis, AQ: spelt 'Gydonis' in ref list - which is correct? 1996; Solntzeva, 1997; Nazarova, 2000). One way to incorporate the special school community into a life-space domain is to combine it with a general school community. It is difficult to accept a new way of thinking and provide services that are not based on personal experiences (York and Vandercook, 1991).
Some teachers are also in two minds about educational integration, considering its establishment in Belarusian society as a result of social crisis and disappointment with the values of the traditional educational system. Sometimes, spontaneous integration happens and takes place when there is no choice at all, or it is picked up occasionally (Shipitzina, 1998; Shmatko, 1999).

\section{MODELS AND FORMS OF} INTEGRATION

At present, in Belarus and in Russia, two models of integration have been developing: internal and external.

\section{Internal integration}

Internal integration takes place in the system of special education, for example: the co-education of deaf children and children with hearing impairments; blind children and those with visual impairments; and pupils with developmental difficulties and those with heavy speech difficulties.

\section{External integration}

The external model is concerned with the interaction of special and general education and has some variants: combined, part-time, temporary and full. With combined integration, children with ageappropriate levels of psychophysical and speech development stay in regular groups and classes and are given the constant special help of a defectologist, who strives to make objectives relevant and functional to the foundation of standard's curriculum (Shmatko, 1999). Part-time integration takes place when children with educational disabilities join other pupils for only some lessons. Temporary integration takes place 1-2 times a month, and involves different kinds of parallel activities.

Educational integration in Belarus has been practised since 1995 in the following forms.

Classes of integrated education: These consist of about 20 people, where there are not more than three pupils with similar severe disabilities or not more than six people with similar mild disabilities. The maximum number of children with different deviations are two to four (two with a heavy pathology or four with a mild pathology but not more than two types of defects). In this context, integrated education may run through either a full completed class with three to six integrated children depending on their disabilities, or a class with fewer disabled children.

There two teachers for one class: a general educator and a defectologist (special educator), who work together. The main part of the lesson is provided by a general teacher, often in two levels. 
Then, a special educator repeats and consolidates this material to a group of disabled children. Sometimes the special educator takes the learning disabled children away from the classroom. This allows for flexible learning environments with flexible curricula and instruction using multiple teaching and learning approaches such as team teaching, co-teaching, peer partners, cooperative learning, heterogeneous grouping, study team planning and parallel teaching. Now, 3030 such classes are open, to which about 6500 pupils (19.3\% of children with special needs) attend with peculiarities of psychophysical development.

Special classes in general school: These comprise 6-12 children with learning difficulties, which is prescribed by the Ministry of Education for each category of disability. Last academic year (2002-2003) there were 489 such classes with 5470 pupils. They use the curriculum and methods of appropriate special schools.

Personal tuition (or correctional-pedagogical consulting): This is a special form of education for disabled children from different rural general schools and for children with temporary learning difficulties owing to long illness.

\section{PROFESSIONAL TRAINING}

Success in special education, as with mainstream education, depends on the quality of educators' professional training to carry out effective upbringing of children with mental and physical disorders and help their social adaptation and integration into society (Nazarova, 2000). This is an important part of the overall process of integration.

The Belarusian State Pedagogical University is one of the most famous centres of defectology in the former Soviet Union. Defectology is an interdisciplinary area of medicine, psychology and teaching for learning disabled children. Wide experience has been gained in this area, but in this changed social and political situation, it needs correction.

New approaches to professional training of defectologists (specialists on mental disorders and physical handicaps) are a result of up-to-date requests for a graduate university student as a special educator, particularly who is able to maintain his or her adaptation to social and economic changes in society.

Within the first 2 years, students acquire essential knowledge of three study blocks: medicine, psychology and teaching. The main courses of medicine are next: anatomy, physiology and pathology of illnesses and functions of man; neurophysiology and neuropathology; sensory systems, psychiatry and pathopsychology; and mental retardation. The psychological block is also wide ranging, comprising general psychology, the psychology of development and personality, social psychology and common special psychology, with different branches according to specific groups of disabled children.

Over 2 years, the students pick up information on all types of disability and gain basic experience in dealing with such subjects. Specialization follows for 3 years in one of four main directions:

Hearing impairment

- Vision impairment

Mental retardation

- Speech and language difficulties.

Usually every person with the university's diploma in defectology has two qualifications in the above mentioned areas, for example therapists specializing in speech therapy and therapy for mentally disabled children.

Since the last academic year, a new subject 'Introduction to Special Pedagogic' AQ: what is 'pedagogic'? has been introduced for students of different faculties. It will help to make integration into education more effective.

\section{CONCLUSION}

Social transformation, the development of democratic and humane trends in education, ideas of worthiness and personal self-importance all make integration an irreversible process. It is a reality to be valued. Nevertheless, development of this process needs planning:

- Scientific research needs to be undertaken into the problems of integrated education to find more appropriate models and reasonable criteria

- Psychological readiness of all participants of this process should be considered

Special literacy of teachers from general schools is required

Designing and implementing the curriculum for each model of integration should be undertaken

- Interaction techniques should be cultivated to coordinate the work of two educators in one class.

Conflict of interest: none. ??? Please state (see covering letter)

Baker ET, Wang MC, Walberg HJ (1994) The effects of inclusion on learning. Educational Leadership 52(4): $33-5$

Unicef (1995) Children and Women of Belarus. Today and Tomorrow. Unicef, Minsk AQ: please cite reference, or shall we delete it?

Furyaeva TV (1999) ?????? [Integrated approach to the organization of upbringing and training disabled children under school age (foreign experience)] Defectology 1: 64-71 AQ: please cite reference or shall we delete it? (If we cite it, the original title is required)

Gydonis (check spelling) VP (1996) ????? [Theoretical preconditions of integration people with visual impairment] Defectology 2: 7-11 AQ: Please provide original title of paper

Heshusius L (1988) The arts, science and the study of exceptionality. Exceptional Children 55(1): 60-5 
Kavale KA, Glass GV (1982) The efficacy of special education interventions and practices: a compendium of metaanalysis findings. In: Focus on Exceptional Children. Love Publishing, Colorado: 1-14

Konopleva AN (1998) ??????? [Problems of integrated education] Defectology 1: 3-8 AQ: Please cite, or shall we delete? (If we cite it, the original title is required)

Konopleva AN, Leshinskaya TL (2001) ?????? [Theory and practice of integrated education] Defectology 2: 3-14 AQ: Please provide original title

Madden NM, Slavin RE (1983) Mainstreaming students with mild handicaps: academic and social outcomes. Reviews of Educational Research 53: 519-69

Milani AA (1996) Disabled students in higher education administrative and judicial enforcement of disability law. The Journal of College and University Law 22: 989-1043

Piuma C (1989) Benefits and costs of integrating students with severe disabilities into regular public school programs: a study summary of money well spent. Unpublished thesis. San Francisco State University, San Francisco

Rutkowski M (1998) ??????? [The experience of integration of disabled children into educational institutes in Poland] Defectology 4: 109-16 AQ: Please provide original title

Shipitzina L (1998) ?????? [Integrative education "for" and "against"] Narodnoye Obrazovanie 6: AQ: Please provide original title and page numbers

Shmatko ND (1999) ????? [Whom can be effective integrated education for?] Defectology 1: 41-6; ? 2: 49-56. AQ: Please provide original title of paper and clarify volume and page numbers

Solntzeva LI (1997) ?????? [Integrated education models of children with visual impairment] Defectology 2: 8-13 AQ: Please provide original title

???? (2000) ???? [Special education] In: Nazarova N, ed Academa. Moscow: 352-62 AQ: Please provide full details of the reference, i.e. name of author, original title of publication, name of publication and volume no or name of publisher

Varenova TV (2000) ?????? [History of educational systems and pedagogical idea] BSPU. Minsk. Please cite, or shall we delete? (If we cite it, full reference is required)

Varenova TV (2002) ?????? [Theory and practice of special education]. ASAR (in press). Please cite, or shall we delete? (If we cite it, full reference is required)

Weiner R (1985) Impact on the School. Capitol publications, Washington

York J, Vandercook T (1991) Designing an integrated program for learners with severe disabilities. Teaching exceptional children. The Council for Exceptional Children 23(2): $22-8$

\section{KEY POINTS}

Integration is a two-way process.

- Specificity of integrated processes is determined by sociocultural conditions of a particular country.

- There are two main kinds of integration: social and educational.

- Educational integration has both positive and negative sides.

- Effective integration is based on external and internal positive criteria. 